\title{
Functional study of CHS gene family members in citrus revealed a novel CHS gene affecting the production of flavonoids
}

\author{
Zhibin Wang ${ }^{1,2}$, Qibin Yu², Wanxia Shen ${ }^{1}$, Choaa A. El Mohtar ${ }^{2}$, Xiaochun Zhao ${ }^{1^{*}}$ and Fredrick G. Gmitter $\mathrm{Jr}^{2^{*}}$ (D)
}

\begin{abstract}
Background: Citrus flavonoids are considered as the important secondary metabolites because of their biological and pharmacological activities. Chalcone synthase (CHS) is a key enzyme that catalyses the first committed step in the flavonoid biosynthetic pathway. CHS genes have been isolated and characterized in many plants. Previous studies indicated that CHS is a gene superfamily. In citrus, the number of CHS members and their contribution to the production of flavonoids remains a mystery. In our previous study, the copies of CitCHS2 gene were found in different citrus species and the sequences are highly conserved, but the flavonoid content varied significantly among those species.

Results: From seventy-seven CHS and CHS-like gene sequences, ten CHS members were selected as candidates according to the features of their sequences. Among these candidates, expression was detected from only three genes. A predicted CHS sequence was identified as a novel CHS gene. The structure analysis showed that the gene structure of this novel CHS is very similar to other CHS genes. All three CHS genes were highly conserved and had a basic structure that included one intron and two exons, although they had different expression patterns in different tissues and developmental stages. These genes also presented different sensitivities to methyl jasmonate (MeJA) treatment. In transgenic plants, the expression of CHS genes was significantly correlated with the production of flavonoids. The three CHS genes contributed differently to the production of flavonoids.

Conclusion: Our study indicated that CitCHS is a gene superfamily including at least three functional members. The expression levels of the CHS genes are highly correlated to the biosynthesis of flavonoids. The CHS enzyme is dynamically produced from several CHS genes, and the production of total flavonoids is regulated by the overall expression of CHS family genes.
\end{abstract}

Keywords: Chalcone synthase, Flavonoid, Gene expression, Gene silencing

\section{Background}

Flavonoids consist of over 7000 compounds and represent a large class of plant secondary metabolites [1-3]. In addition to being the primary compounds that determine the colour of flowers, fruits and leaves, flavonoids play important roles in protecting plants against damage from pathogens, pests and herbivores $[4,5]$, conferring resistance to abiotic stresses [6], and transporting plant hormones in diverse signalling pathways [7]. Flavonoids

\footnotetext{
* Correspondence: zhaoxiaochun@cric.cn; fgmitter@ufl.edu

${ }^{1}$ Citrus Research Institute, Southwest University, Xiema, Beibei, Chongqing 400715, China

${ }^{2}$ Citrus Research and Education Center, University of Florida, 700 Experiment Station Rd, Lake Alfred, Florida 33850, USA
}

also have multiple benefits for human health [8], such as the prevention of cardiovascular and carcinogenic risks, promotion of antioxidant and anti-inflammatory activity, and protection against coronary heart disease and certain cancers [9-12].

Flavonoids are produced by all citrus species, such as mandarins, sweet or sour oranges, pummelos, grapefruits, limes and lemons [13]. Thus far, more than 60 flavonoid compounds have been identified in citrus. Those flavonoids can be classified into four major types of substances named flavones, flavonols, flavanones, and flavanonols according to their basic structures $[14,15]$. Compared with other plant flavonoids, certain citrus flavonoids possess

(c) The Author(s). 2018 Open Access This article is distributed under the terms of the Creative Commons Attribution 4.0 International License (http://creativecommons.org/licenses/by/4.0/), which permits unrestricted use, distribution, and 
much stronger antioxidant activity due to their unique chemical structures [16-18].

The biosynthesis of flavonoids in plants has been well characterized [19, 20]. Although chalcone synthase (CHS) was identified as the first enzyme involved in the flavonoid biosynthesis pathway in 1972 [21], CHS was not reported in citrus until 1989 [22]. CHS controls the first committed step of flavonoid biosynthesis and catalyses three molecular malonyl CoA and one molecular 4-coumaroyl CoA into naringenin chalcone, which is then rapidly converted into naringenin (flavanone) by chalcone isomerase $(\mathrm{CHI})$ and further synthesized into various flavonoids by the downstream enzymes involved in this pathway $[23,24]$. Therefore, understanding the function of the CHS gene and its regulatory mechanism is vital to exploring the genetic control of this metabolite pathway.

In many dicots, $\mathrm{CHS}$ is encoded by a multigene family [25-27]. Usually, the chalcone synthase gene forms a family of three to twelve members in most of dicots, such as apple (3 members) [28], mulberry (5 members) [29], Populus (6 members) [30], Glycine max (8 9 members) [31, 32], Viola cornuta (10 members) [33], and petunia (12 members) [34]. In turnip, six CHS genes were cloned and identified, although only three were functional. The other three $\mathrm{CHS}$ genes were confirmed to be redundant genes [27]. In Valencia orange, two CHS (CitCHS1 and CitCHS2) genes were identified by Southern blotting. The expression of the two CHS genes in relation to the biosynthesis of flavonoids was very different in citrus cell cultures. CitCHS2 was found to strongly regulate the accumulation of flavonoids, but CitCHS1 did not [35]. In our early study, the CDS (Coding Sequence) fragments of the CitCHS2 gene cloned from ten different citrus species demonstrated high identity [36]. The analysis of flavonoid contents revealed significant differences among different species. However, a strong correlation between the expression of the CitCHS2 gene and the accumulation of flavonoids is only present in a few species.

In the current study, seventy-seven $\mathrm{CHS}$ or $\mathrm{CHS}$-like genes were studied to explore the structure and expression profile of the CHS gene family in citrus. The function of the CHS genes was verified by both overexpression and gene silencing via transgenic experiments. The $C H S$ gene family and its activity in regulating the biosynthesis of flavonoids in citrus is discussed.

\section{Results}

\section{Phylogenetic analysis of the CHS family genes}

The CHS gene has been reported to be a member of the PKS (Polyketide synthase) superfamily in plants [37]. A phylogenetic tree of the CHS family genes was constructed using the ClustalW method based on the substitution of amino acid residues of the CHS and CHS-like genes derived from citrus genome sequence databases (NCBI (https://www.ncbi.nlm.nih.gov/gene), Phytozome (https://phytozome.jgi.doe.gov/pz/portal.html) and Orange Genome Annotation Project (http://citrus.hzau.edu.cn/cgi-bin/orange/search)). The seventy-seven $\mathrm{CHS}$ and $\mathrm{CHS}$-like genes were clustered into mainly three groups (Fig. 1). A more divergent structure of subgroups was found in group I. Group III was noticeably distant from group I and II. The genes in group I and II shared a higher similarity than they do with those in group III. The annotation indicated that most genes from group I and II are the non-functional NADPH-dependent codeinone reductase 2-like gene or type III polyketide synthase related genes. A high identity $(75.0 \%$ to $88.2 \%, 1$ : Table S1) among CitCHS1, CitCHS2 and other 20 genes in group III was observed, which suggested that the citrus $C H S$ family may include many members.

\section{Expression profiles of CHS genes with or without MeJA treatment}

To identify the functional members of the CHS family, ten candidate genes from each subgroups of group III of the phylogenetic tree were selected according to their similarity and structures and used for the gene expression analysis via qPCR with gene-specific primers (Additional file 1: Table S2). The transcripts were only detected from three genes with or without methyl jasmonate (MeJA) treatment. CitCHS1 (CICLE_v10005133m) and CitCHS2 (CICLE_v10015535m) were two of the three genes mentioned above. The third one, CICLE_v10 $001405 \mathrm{~m}$, has not yet been reported in any publication; it is distinct from the other two CHS genes and located in a different subgroup of the phylogenetic tree. This gene was named CitCHS3 in the present study.

The expression of the $C H S$ genes was tissue specific (Fig. 2). These three genes did not express in the root in the absence of the MeJA treatment. CitCHS1 was not detected in the cotyledon and leaf before the MeJA treatment. However, all three $\mathrm{CHS}$ genes were expressed in the stem. MeJA induced the expression of all three genes in the root. The results demonstrated that the three CHS genes responded differently to the MeJA treatment. Overall, CitCHS1 showed the greatest response to the MeJA treatment among the three genes. The expression pattern of the three genes in response to MeJA is tissue specific. In the root, MeJA enhanced the expression of all three genes, particularly CitCHS2 and CitCHS3 after the first two MeJA application. CitCHS2 and $\mathrm{CitCHS} 3$ present similar expression profiles in the stem, cotyledon and leaf. MeJA suppressed the expression of these two CHS genes at the early stage of treatment but enhanced the expression at the late stage. CitCHS1 showed similar expression pattern as the other 


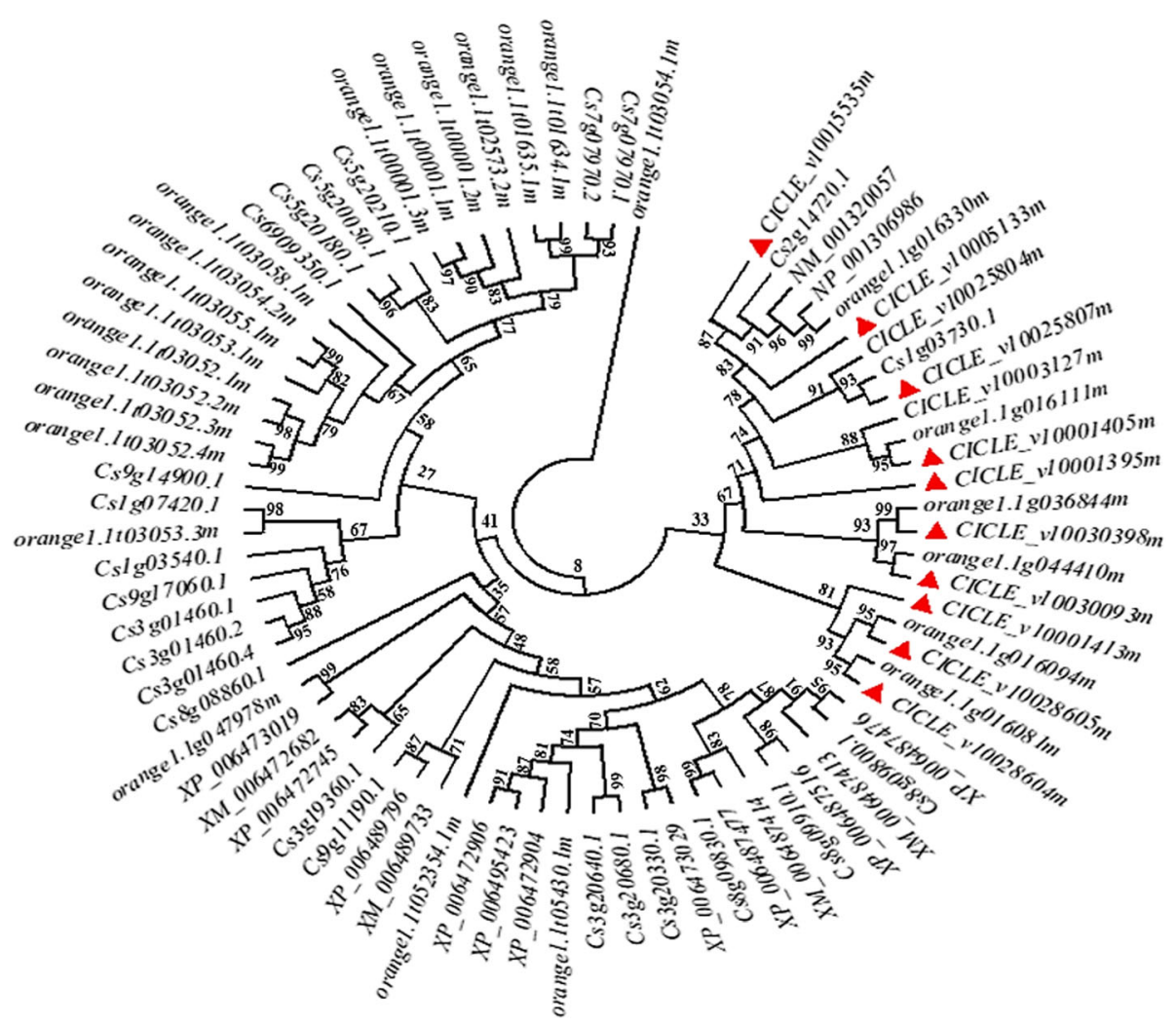

Fig. 1 Phylogenetic tree based on the amino acid sequences of 77 chalcone synthase proteins. Among these sequences, 9 (XM_006487413.1, XM_006487414.2, XM_006472682.2, XM_006489733.1, NM_001320057.1, NM_001320057.1, XM_006489733.1, XM_006472682.2) were derived from NCBI, 16 (ClCLE_v10001405 m, CICLE_v10001413 m, CICLE_v10003127 m, ClCLE_v10005133 m, CICLE_v10015535 m, ClCLE_v10028604 m, CICLE_v10028605 m, CICLE_v10030093 m, ClCLE_v10030398 m, orange1.1 g016081 m, orange1.1 g016094 m, orange1.1 g016111 m, orange1.1 g016330 m, orange1.1 g036844 m, orange1.1 g044410 m, orange1.1 g047978 m) were derived from Phytozome and the remaining 52 were derived from the Orange Genome Annotation Project. The red triangle represents the selected candidate sequences used for the expression analysis. The alignments were saved and executed using MEGA version 7.1 to generate a neighbour-joining tree with a bootstrapping (1000 replicates) analysis, and gaps were addressed via pairwise deletion

two genes in the stem, although its expression was enhanced in the cotyledon and leaf.

\section{MeJA treatment induced the production of flavonoids}

To investigate the distribution of total flavonoids in the four tissues, the contents of four main types of flavonoids, i.e., flavones, flavonols, flavanones and flavanonols, were analysed in the seedlings. In the roots, the highest contents of each flavonoid component were detected at time T0 before the MeJA treatment. A sharp decrease in flavonoid contents was observed after the MeJA application, and the content reached a very low level at $12 \mathrm{~h}$ after spraying (T1) (Fig. 3). The contents of flavonoids did not significantly change from $\mathrm{T} 1(12 \mathrm{~h}$ after treatment) to $\mathrm{T} 5$ (60 h after treatment), only showed slight fluctuations; however, the lowest content of each flavonoid appeared at T0 in the leaves. In leaves, MeJA induced the production of flavonoids in the first $12 \mathrm{~h}$ after treatment, and this effect gradually declined through T2 until T3. In the cotyledons and stems, the contents of flavonoids had a similar variation tendency as that in the roots, but the level of variation was much less significant.

\section{Correlation between CitCHS expression and flavonoid production under MeJA treatment}

To identify the function of the three CitCHS genes, the correlation between gene expression and flavonoid accumulation was studied (Table 1). Among the three CHS genes, the expression of CitCHS1 was not positively correlated with the flavonoid content, including the four primary compounds, in most tissues except the roots, which showed a correlation coefficient of 0.77 between the expression level and total flavonoids. The expression level of the other two genes, CitCHS2 and CitCHS3, was positively correlated with individual flavonoid accumulation in the root, cotyledon and stem, but not the leaf. However, the expression level of both CitCHS2 and CitCHS3 was found to be correlated with the accumulation of total flavonoids in the leaf. The highest 


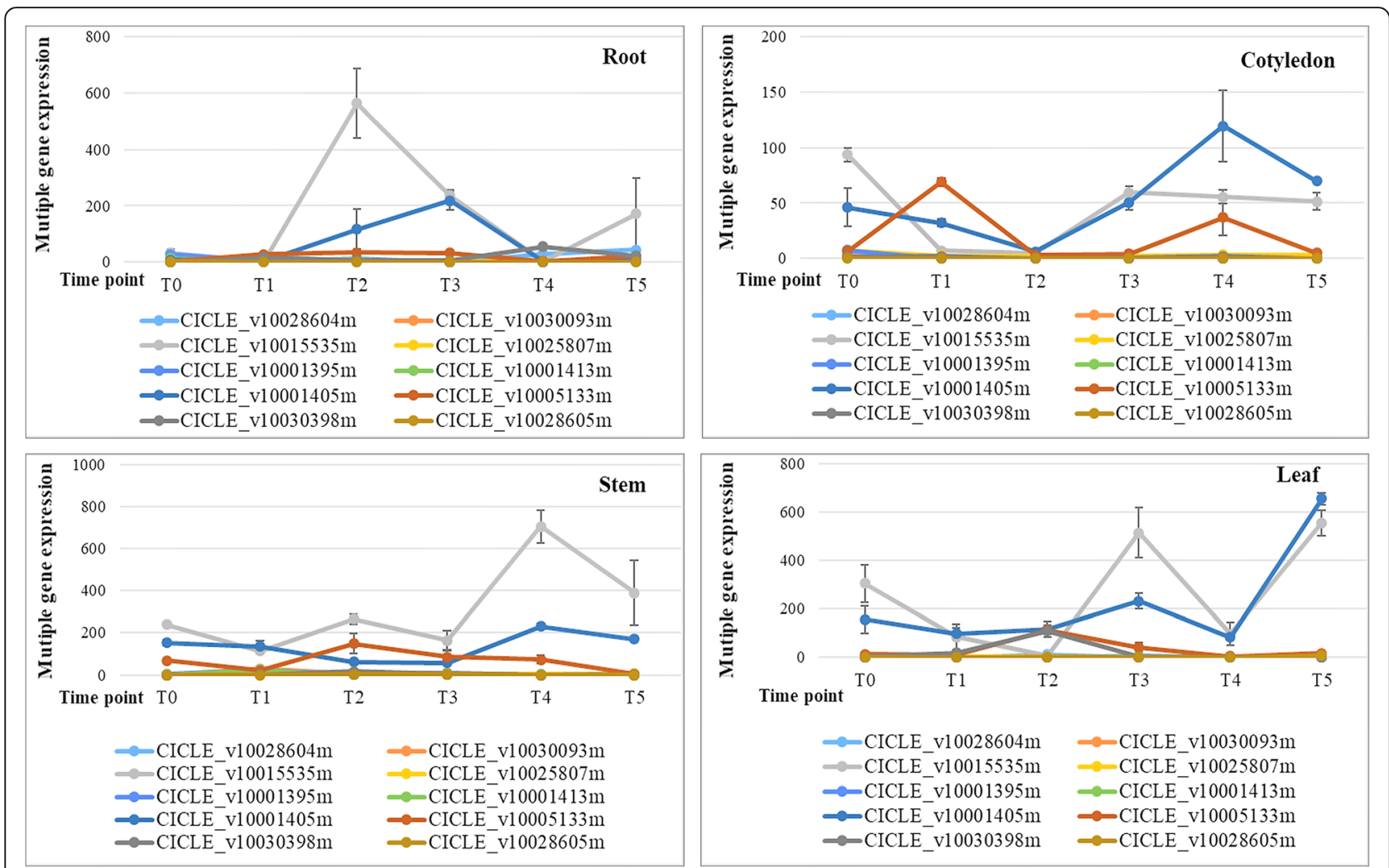

Fig. 2 Differential expression patterns of the 10 CHS candidates in young seedlings with or without the MeJA treatmentThe ordinate $Y$ is the

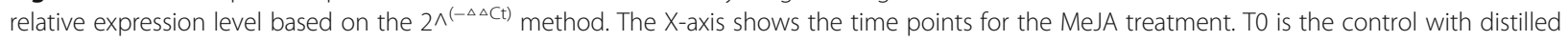
water. T1 (12 h) is $12 \mathrm{~h}$ after MeJA treatment (same convention for T2 (24 h), T3 (36 h), T4 (48 h), and T5 (60 h))

correlation for CitCHS2 was found in the stem $(R=0.81)$. CitCHS3 was found to be positively correlated with flavones and flavonols in the root, with flavanones and flavanonols in the cotyledon and stem. Interestingly, the expression of $\mathrm{CitCHS} 3$ was more significantly correlated with the content of flavanones and flavanonols and total flavonoids in the root and cotyledon than was that of CitCHS2, although the opposite trend was observed in the stem and leaf. However, the overall expression level of CitCHS was highly correlated with the total flavonoid accumulation in the root, cotyledon, stem and leaf. Moreover, the three CitCHS genes were co-expressed in the root with coefficients of $0.67,0.64$ and 0.60 , respectively. In the other three tissues, co-expression was only found between CitCHS2 and CitCHS3.

\section{Constitution of the CitCHS genes}

CitCHS2 (Accession No. KP720583-KP720592) was cloned from ten different citrus species in our previous work [36]. The cDNAs of CitCHS1 (Accession No. MF784513) and CitCHS3 (Accession No. MF776052) were amplified from grapefruit (Citrus paradisi Macf. cv. Duncan) and 'Sunred' (a red-fleshed hybrid of C. clementina Oroval $\times$ C. sinensis Moro blood orange), respectively, in this study. The lengths of the CDS of CitCHS1, CitCHS2 and CitCHS3 were 1170 bp, 1176 bp and 1194 bp, respectively. The DNA sequence of the three CHS genes consisted of one intron and two exons, and the first exon was much smaller than the second. Moreover, the length of the first exon for each of the three CHS genes was the same at 180 nucleotides, representing 60 amino acids. The DNA sequence of the three $C H S$ genes showed variation in the second exon. Based on the constructed structure of $\mathrm{CHS}$ in alfalfa [37], the sequence of amino acids showed that the three CHSs obtained from citrus plants contained almost all the main features of the CHS model structure (Fig. 4). This analysis indicated that the three citrus CHS genes are the active $C H S$ genes.

\section{Functional validation of CitCHS genes with transgenic plants}

Virus-induced gene silencing (VIGS) was conducted to validate the function of the three CitCHS genes. Four positive plants were selected from the transgenic plants to analyse the correlation between gene expression and flavonoid production. The non-transgenic plants and plants transformed with the empty vector were used as controls. The three CitCHS genes showed reduced expression in 


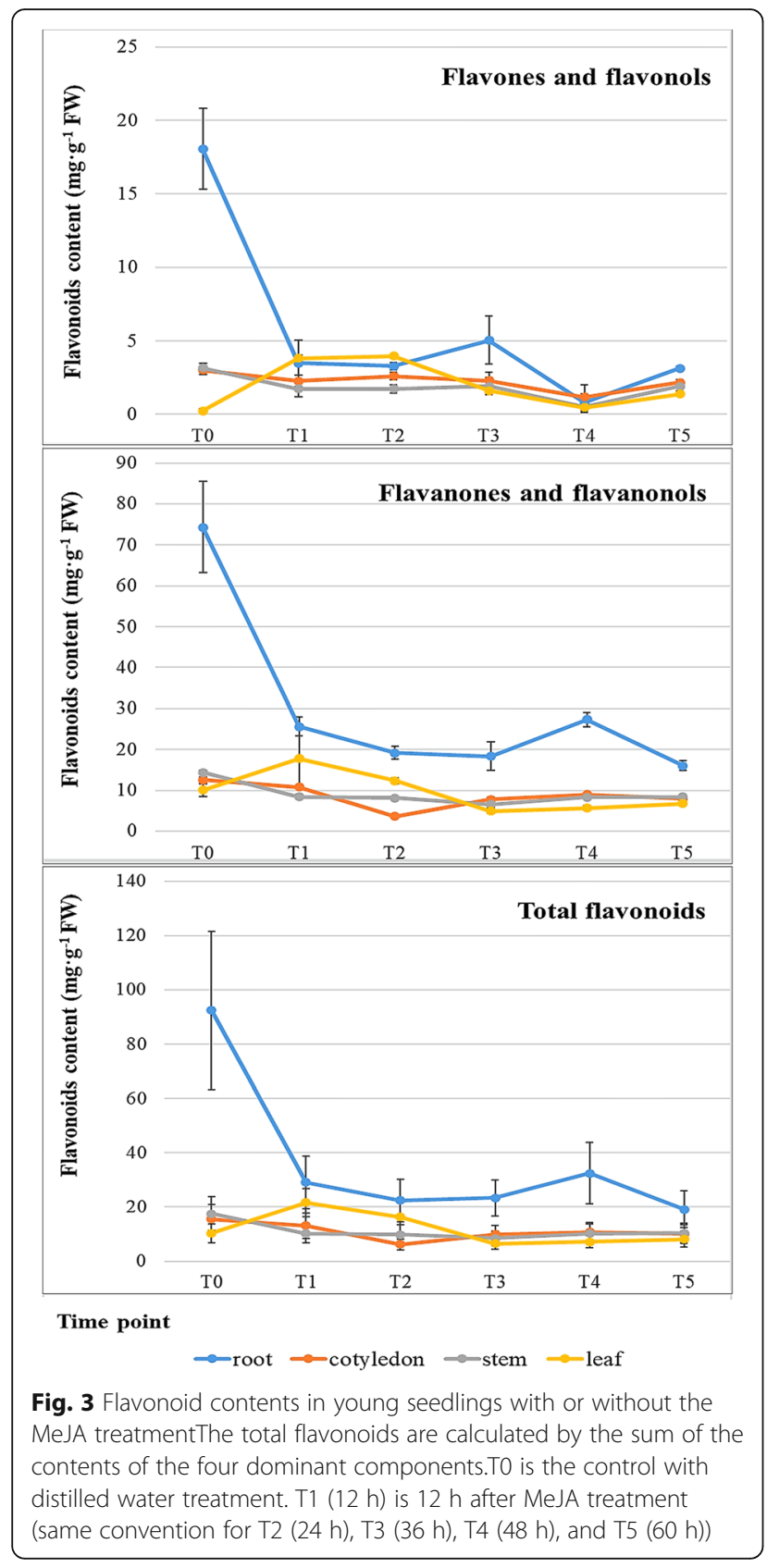

the plants transformed with an empty vector, at 53.83\%, $54.71 \%$ and $69.18 \%$ of reductions compared with those of the non-transgenic control. However, the reduced gene expression in the empty vector transgenic plants did not result in a significant decrease in the flavonoid content, with only a $3 \%$ reduction in total flavonoids. Large differences in the expression of the three CitCHS genes were observed in the non-transgenic control plants. CitCHS2 showed the highest levels of transcripts, whereas CitCHS1 presented a low level. In all four transgenic plants, three CitCHS genes were not completely silenced, although the level of expression was significantly suppressed (Fig. 5).
The average levels of suppression of the three CHS in transgenic plants were $81.03 \%, 79.67 \%$ and $76.60 \%$. Large variations in the level of suppression were observed among the transgenic plants, although the average level of suppression among the three genes was only slightly different from that of the non-transgenic control, which suggested that VIGS has an equal effect on the three CitCHS genes.

The silenced plants produced significantly fewer flavonoids than did the controls. The level of reduction among the four types of flavonoids was different (Fig. 5). Suppressing the expression of the CitCHS genes in the silenced plants resulted in a significant reduction of flavone and flavonol production but had less effect on the production of flavonones and flavanonols. However, the total flavonoid production decreased by $41.11 \%$ compared with that in the non-transgenic control. The results indicated the importance of CitCHS genes for the production of flavonoids.

The contribution of the three CitCHS genes towards the production of flavonoids is not similar. The reduced CHS gene expression in the empty vector control transgenic plants did not have a lower production of flavonoids. Excluding the empty vector control from analysis, strong correlations of $0.90,0.43$ and 0.80 were observed between the level of gene expression and the total flavonoid content for the three $\mathrm{Cit} C H S$ genes.

To identify the contribution of $C H S$ genes to the accumulation of flavonoids, four positive overexpression transgenic citrus plants were analysed for both gene expression and flavonoid accumulation. Among the four positive plants, only three (OE-1, OE-3 and OE-4) showed up-regulated CHS expression (Fig. 6). An apparent increase in the production of flavonoids was observed in OE plants. The OE-2 plant showed the lowest level of $\mathrm{CHS}$ expression and flavonoid content among the four OE plants. The CHS gene overexpression results also indicated that the CHS genes contributed significantly to the production of flavonoids.

\section{Discussion}

The function of the CHS gene in controlling flavonoid biosynthesis has been well-documented in many plant species [22-24]. The CHS superfamily has also been reported in many plants such as soybean [32], turnip [27] and mulberry [29]. Thus far, studies have not discussed the phenomenon of the CHS superfamily or functional members of this family in citrus plants. In this study, the phylogenetic analysis of $77 \mathrm{CHS}$ or CHS-related genes from the citrus genome revealed that the citrus $\mathrm{CHS}$ family may include many members. The expression of three CHS members from 10 candidates were identified in different tissues of young seedlings, suggesting that they are active in citrus. One of them appeared as a novel CHS gene and was termed as CitCHS3. Though, 
Table 1 Pearson's correlation coefficients between gene expression and flavonoid accumulation in four tissues of young seedlings based on time point T0-T5

\begin{tabular}{|c|c|c|c|c|c|c|c|}
\hline & & $F V+F V L$ & $F N+F N L$ & TF & CHS1 & CHS2 & CHS3 \\
\hline \multirow[t]{4}{*}{ Root } & CHS1 & $-0.18^{\mathrm{NS}}$ & $-0.5^{\mathrm{NS}}$ & $0.77^{* * *}$ & & & \\
\hline & CHS2 & $0.39^{* * * *}$ & $0.19^{\mathrm{NS}}$ & $0.48^{* * * *}$ & $0.67^{* * *}$ & & \\
\hline & CHS3 & $0.52^{* * *}$ & $0.26^{N S}$ & $0.67^{* * *}$ & $0.64^{* * *}$ & $0.6^{* * *}$ & \\
\hline & CHSs & $0.45^{* * *}$ & $0.2^{\mathrm{NS}}$ & $0.59^{* * * *}$ & $0.75^{* * *}$ & $0.96^{* * *}$ & $0.79^{* * *}$ \\
\hline \multirow[t]{4}{*}{ Cotyledon } & CHS1 & $-0.544^{\mathrm{NS}}$ & $0.11^{\mathrm{NS}}$ & $0.05^{\mathrm{NS}}$ & & & \\
\hline & CHS2 & -0.01 NS & $0.49^{* * * *}$ & $0.52^{* * * *}$ & $-0.37^{\mathrm{NS}}$ & & \\
\hline & CHS3 & $-0.02^{\mathrm{NS}}$ & $0.62^{* * *}$ & $0.65^{* * * *}$ & $0.03^{N S}$ & $0.5^{* * *}$ & \\
\hline & CHSs & $-0.31^{\mathrm{NS}}$ & $0.58^{* * *}$ & $0.58^{* * *}$ & $0.38^{* * *}$ & $0.59^{* * *}$ & $0.85^{* * *}$ \\
\hline \multirow[t]{4}{*}{ Stem } & CHS1 & $0.46^{* * *}$ & $0.29^{N S}$ & $0.34^{* * *}$ & & & \\
\hline & CHS2 & $0.45^{* * *}$ & $0.45^{* * *}$ & $0.8^{* * * *}$ & 0.01 NS & & \\
\hline & CHS3 & $-0.09^{\mathrm{NS}}$ & $0.44^{* * *}$ & $0.34^{* * * *}$ & $-0.53^{\mathrm{NS}}$ & $0.76^{* * *}$ & \\
\hline & CHSs & $0.42^{* * * *}$ & $0.86^{* * *}$ & $0.79^{* * * *}$ & $0.07^{N S}$ & $0.99^{* * *}$ & $0.75^{* * *}$ \\
\hline \multirow[t]{4}{*}{ Leaf } & CHS1 & 0.01 NS & $-0.85^{\text {NS }}$ & $-0.77^{\mathrm{NS}}$ & & & \\
\hline & CHS2 & -0.64 NS & 0.01 NS & $0.59^{* * * *}$ & -0.31 NS & & \\
\hline & CHS3 & $-0.07^{\mathrm{NS}}$ & $0.05^{\mathrm{NS}}$ & $0.39^{* * *}$ & $-0.16^{\mathrm{NS}}$ & $0.78^{* * *}$ & \\
\hline & CHSs & $-0.39^{\text {NS }}$ & $-0.05^{\text {NS }}$ & $0.48^{* * *}$ & $-0.16^{\mathrm{NS}}$ & $0.94^{* * *}$ & $0.94^{* * *}$ \\
\hline
\end{tabular}

Note: FV + FVL, Flavones and flavonols; FN + FNL, Flavanones and flavanonols; TF, Total flavonoids; CHSs, total CHS; CHS1, CitCHS1; CHS2, CitCHS2; and CHS3, CitCHS3

NS=Not significantly different at $P<0.05 ; * *$ Significant at $P<0.001$

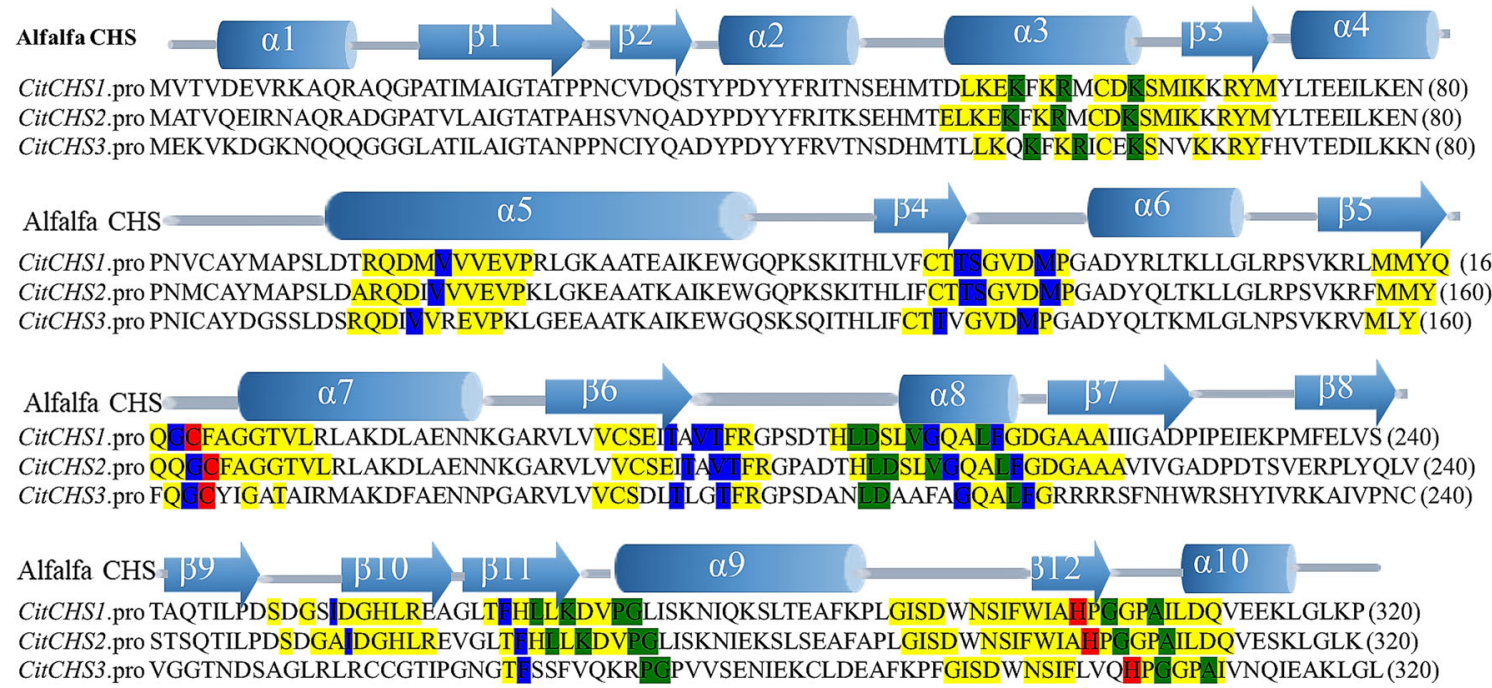

CitCHS1.pro MVTVDEVRKAQRAQGPATIMAIGTATPPNCVDQSTYPDYYFRITNSEHMTDLKERFFRMCDKSMIKKRYMYLTEEILKEN $(80)$ CitCHS2.pro MATVQEIRNAQRADGPATVLAIGTATPAHSVNQADYPDYYFRITKSEHMTELKEK FKRMCDKSMIKKRYMYLTEEILKEN (80) CitCHS3.pro MEKVKDGKNQQQGGGLATILAIGTANPPNCIYQADYPDYYFRVTNSDHMTLLKQERKRICEKSNVKKRYFHVTEDILKKN (80)

CitCHS2.pro STSQTILPDSDGA|DGHLREVGLT HLLKDVPGLISKNIEKSLSEAFAPLGISDWNSIFWIAHPGGPAILDQVESKLGLK (320)
CitCHS3.pro VGGTNDSAGLRLRCCGTIPGNGTISSFQKRPGPVVENIEKCLDEAFKPFGISDWNSIFLVQIIPGGPIVNQIEAKLGL (320)

Fig. 4 Structure and activity sites of the three CHS genes obtained from citrusThis figure was drawn according to Austin and Noel [37]. Key sections are highlighted in yellow. The CHS catalytic triad, residues bound to COA, and other residues important for functional diversity are highlighted in red, green, and blue, respectively. For clarity, only identical residues in the equivalent positions of the aligned sequences are highlighted 


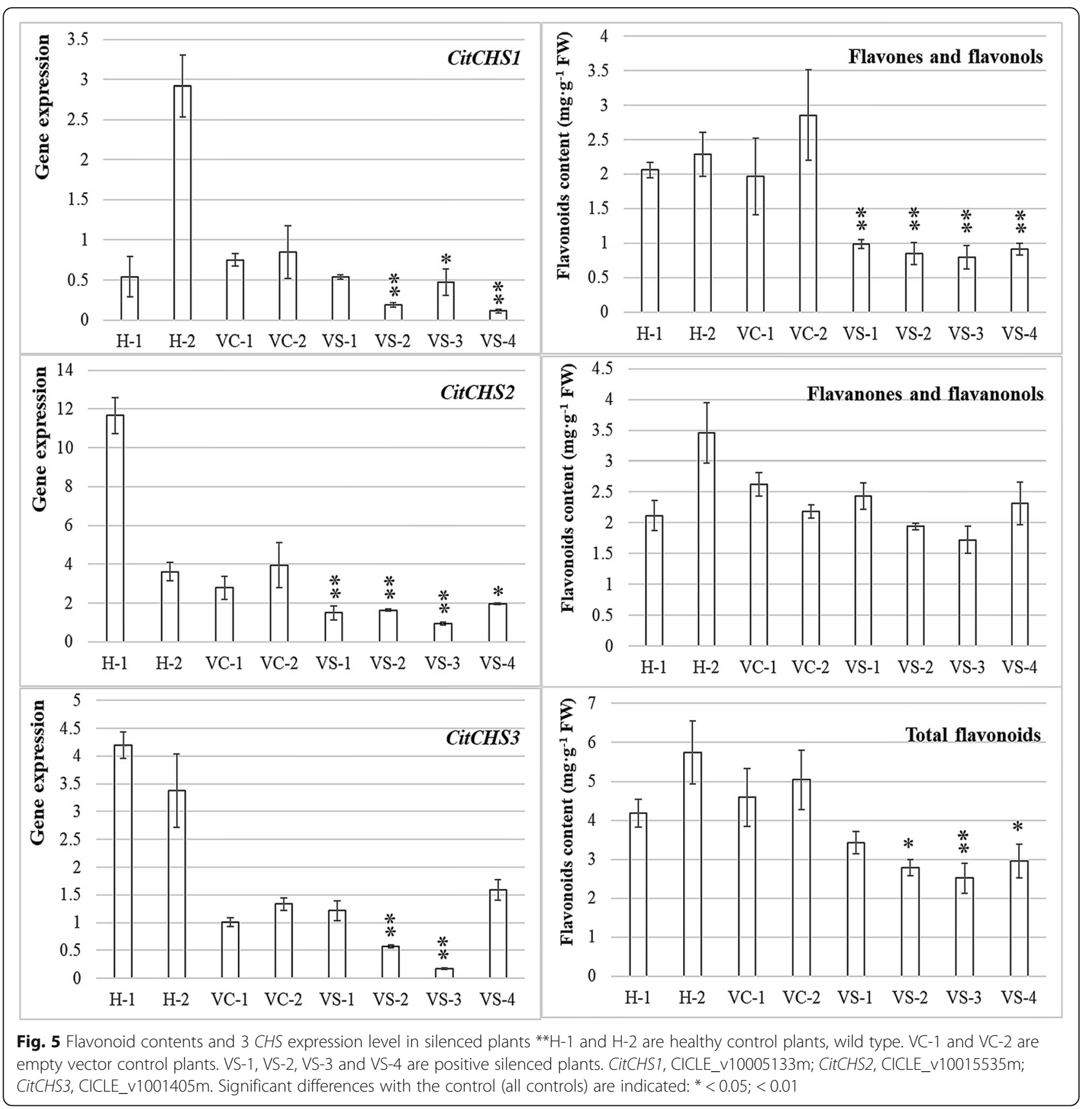

the level of transcripts was detected in another gene, CICLE_v10030398m at T4 in root and at T2 in leaf. We did not carry on the further work to characterize the function of this gene in this study because it only temporarily expressed under the MeJA treatment. Plant hormone, like JA/MeJA (Jasmonate/Methyl jasmonate) can modulate CHS gene expression [38]. It was reported that both ABA and JA are vital signalling molecules in plants as they can induce stress-resistance and participate in the formation of systemic resistance, through the wound signal transduction pathway [39]. Certain chemical elicitors, such as ABA, SA, JA can mimic environmental stress [40], induce the expression of $C H S$ and enhance the activity of CHS in many plants [41-43]. Cross-talk between these chemical signaling pathways is very common in plant responses to abiotic and biotic factors. In the present study, the 'Sunred' blood orange hybrid seedlings were treated with MeJA to identify the activity of CHS genes. Of 10 selected CHS and CHS-like genes, the three $\mathrm{CHS}$ genes including $\mathrm{CHS} 3$ greatly responded to the MeJA treatment. This result confirmed that MeJA could enhance the expression of CHS genes. The correlation analysis showed that there is a tight relationship between flavonoid accumulation and $C H S$ expression in 


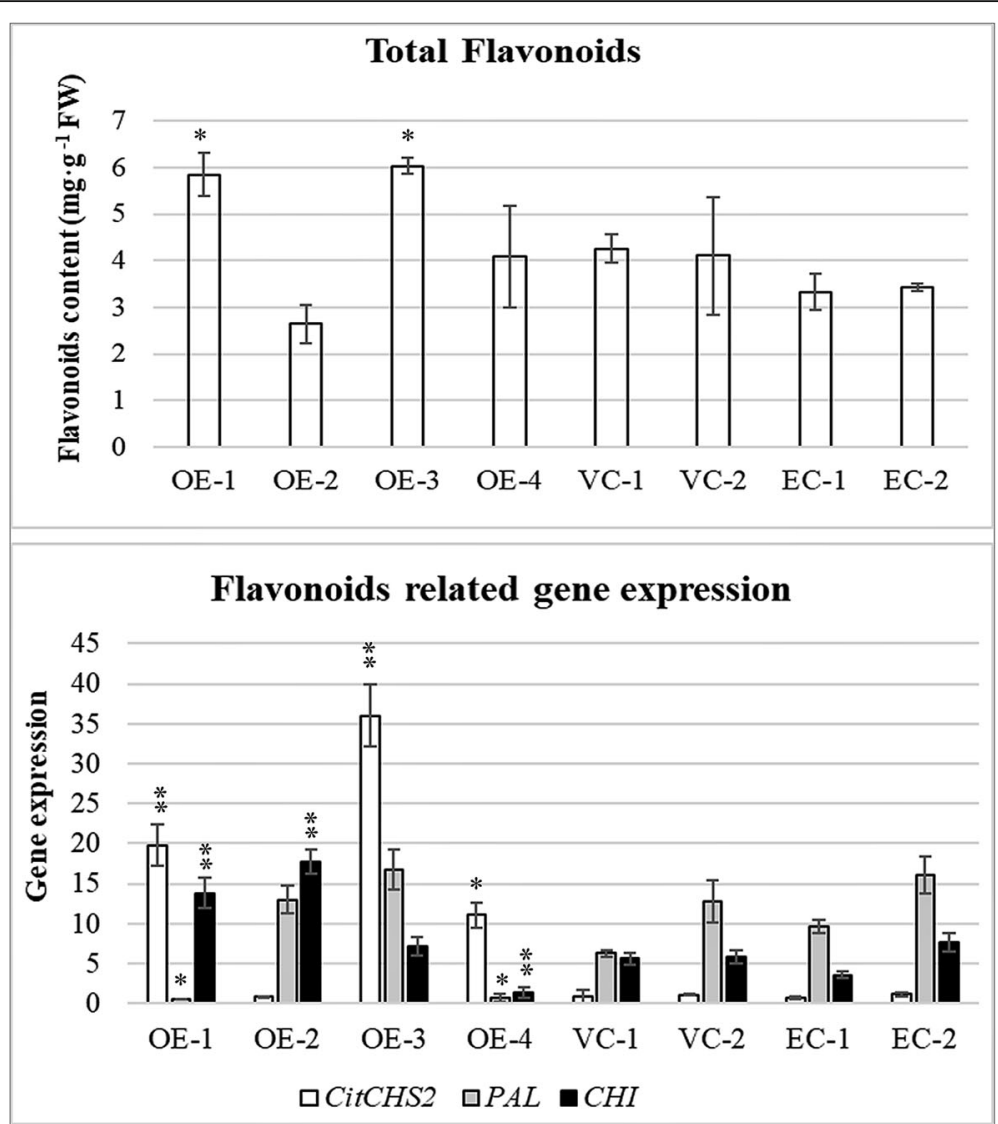

Fig. 6 Flavonoid content and expression level of flavonoid production-related genes in over-expression plants **VC-1 and VC-2 are vector-only control plants. EC-1 and EC-2 are healthy control plants, wild type. OE-1, OE-2, OE-3 and OE-4 are positive over-expression plants. Significant differences with the control (all controls) are indicated: ${ }^{*}<0.05 ;<0.01$

the MeJA-treated plants. However, the levels of expression of the three CHS genes as well as their correlation with the accumulation of flavonoids were different. The expression of all three CHS genes demonstrated significant correlations with the accumulation of total flavonoids, indicating the importance of $\mathrm{CHS}$ for controlling the biosynthesis of flavonoids in citrus.

In citrus, the $C H S$ gene appeared as a large gene family, as reported in other plants. Two CHS genes (CitCHS1 and CitCHS2) were reported in previous studies [35]. Three copies of the CitCHS2 gene were identified in Citrus. sinensis (L.) Osbeck cv. Ruby. They were located on three different chromosomes [44]. Nine CHS genes were studied in 'Rio Red' grapefruit (C. paradisi.) [24]. These CHS genes shared $86-87 \%$ and $97-99 \%$ similarities with CitCHS1 and CitCHS2, respectively. Presumably, these genes should be the copies of different CitCHS members. Only a slight difference was observed in the amino acid sequences among most $C H S$ genes in citrus, although variations in their activity in the control of flavonoid biosynthesis were observed. Therefore, we attempted to study the functional characteristics of $C H S$ members in this study.
Comparison of genomic DNA sequence, the cDNA structure of the CHS gene had an intron and two exons with the same length of 60 amino acids in the first exon and shared over $90 \%$ sequence similarity, whereas the second exons were much less conserved, which indicated that the first exon is important for the activity of chalcone synthase because it is part of the basic structure of CHS. The novel CHS gene identified in this study (i.e., CitCHS3) shared high identity with the reported CHS and demonstrated a close correlation with the production of flavonoids. This novel CHS should represent a new member of the CitCHS family, suggesting that the CHS gene family in citrus contains at least three functional members and each member may have multiple copies.

Among these three functional members, the expression of CitCHS1 was not induced by embryogenesis in citrus [35]. Similarly, the present study showed that the expression level of CitCHS1 was low and maintained a relatively steady level in the four studied tissues compared with the other two CitCHS genes. Thus, CitCHS1 is likely a tissue-specific gene or is not sensitive to MeJA treatment. CitCHS2 is a well-recognized gene. In this 
study, the CitCHS3 gene demonstrated a high level of expression. The correlation analysis also showed that the $\mathrm{CitCHS} 3$ gene was co-expressed closely with $\mathrm{CitCHS2}$ $(r>0.83)$ and had a high correlation $(r=0.6)$ with the accumulation of total flavonoids in silenced plants (Table 2).

Although the reduction of the CHS expression were found in the empty vector control plants with $3 \%$ of flavonoids reduction. The reduction of both the CitCHS gene expression and the flavonoids contents are significantly correlated in the silenced plants, in comparison with both non-transgenic control and empty vector control plants.

CHS is located at an important regulatory point upstream of the flavonoid biosynthetic pathway. It can channel the flux of the phenylpropanoid pathway towards flavonoid biosynthesis [43]. Thus, up- or down-regulation of $\mathrm{CHS}$ gene expression may strongly affect the production of flavonoids. In previous study, PAL (Phenylalanine ammonia-lyase) shared a similar expression pattern with $C H I$ [45], though no consistent rules were found regarding $P A L$ expression or its influence on CHS in pears [46]. We also tried to illuminate the correlation among $P A L, C H S$ and $C H I$. Our result showed that the overexpression of $\mathrm{CHS}$ maybe positively affect the expression of $\mathrm{CHI}$ gene, which is located downstream of $C H S$, but no obvious influence can be found to $P A L$ gene, which is located upstream of CHS in the flavonoid biosynthesis pathway.

\section{Conclusions}

A novel CHS gene named CitCHS3 (Accession No. MF776052) was identified in citrus plants. CHS is a superfamily in the citrus genome with at least three functional genes that can regulate the biosynthesis of flavonoids. Three CitCHS genes have unique spatial and temporal expression properties and contribute differently to the production of flavonoids.

\section{Materials and methods}

Plant materials and methyl jasmonate treatment

Seeds were collected from the mature fruits of 'Sunred' blood orange hybrid $(C$. clementina Oroval $\times$ C. sinensis

Table 2 Pearson's correlation coefficients between gene expression and flavonoid accumulation in silenced plants

\begin{tabular}{llllllllll}
\hline Coefficient analysis & \multicolumn{1}{l}{ CitCHS1 } & \multicolumn{2}{l}{ CitCHS2 } & \multicolumn{2}{l}{ CitCHS3 } & \multicolumn{2}{l}{ Total CHSs } \\
\hline FV + FVL & 0.55 & $* * *$ & 0.51 & $* * *$ & 0.52 & $* * *$ & 0.60 & $* * *$ \\
FN + FNL & 0.86 & $* * *$ & 0.02 & NS & 0.49 & $* * *$ & 0.31 & $* * *$ \\
TF & 0.79 & $* * *$ & 0.37 & $* * *$ & 0.58 & $* * *$ & 0.57 & $* * *$ \\
CitCHS1 & & & 0.08 & NS & 0.50 & $* * *$ & 0.38 & $* * *$ \\
CitCHS2 & & & & & 0.83 & $* * *$ & 0.95 & $* * *$ \\
CitCHS3 & & & & & & & 0.95 & $* * *$ \\
\hline
\end{tabular}

Note: FV + FVL, Flavones and flavonols; FN + FNL, Flavanones and flavanonols; TF, Total flavonoids. NS=Not significantly different at $P<0.05 ;{ }^{* * *}=$ Significant at $P<0.001$
'Moro') in the field of CREC, UF, on Nov. 2016. The seeds were germinated in soil after the removal of both outer and inner seed coat and grown in a greenhouse under a natural light cycle. Four-week-old seedlings were used in this study. JA/MeJA can modulate CHS gene expression [38]. MeJA (Sigma Company, USA) was prepared at a concentration of $200 \mu \mathrm{M}$ according to the method of Shi [47]. The seedlings were sprayed with MeJA every $12 \mathrm{~h}$ immediately after sampling. The control was sprayed with distilled water. The leaf, stem, cotyledon and root samples were collected every $12 \mathrm{~h}$. $\mathrm{T} 0$ is the control without any treatment (only water). T1 $(12 \mathrm{~h})$ is $12 \mathrm{~h}$ after treatment (same convention for T2 (24 h), T3 (36 h), T4 (48 h), and T5 (60 h)). Samples from 10 to 15 seedlings were mixed together, with three replications performed for each time point. The samples were immediately rinsed in distilled water, placed into liquid nitrogen for freezing, and then stored at $-80{ }^{\circ} \mathrm{C}$ for further use. The samples were ground into a fine powder in liquid nitrogen for both RNA extraction (Agilent Plant RNA Isolation Kit (Agilent, USA)) and flavonoids detection.

\section{Total RNA isolation and CDNA synthesis}

Total RNA was extracted according to the protocol of the Agilent Plant RNA Isolation Kit (Agilent, USA). The integrity and concentration of RNA were determined via 2.0\% agarose gel electrophoresis and a NanoDrop 2000 spectrophotometer (Thermo, Waltham, MA, U.S.A.), respectively. One microgram of DNA-free RNA was initiated using a mixed primer (oligo $(\mathrm{dT})$ : random primer $=$ 1.7:0.3, V: V, concentration: $10 \mu \mathrm{M})$ for first-strand cDNA synthesis with an Affinity Script QPCR cDNA Synthesis Kit (Agilent, USA) following the manufacturer's instructions. The product was diluted in a 4-fold volume of sterile deionized water and stored at $-20{ }^{\circ} \mathrm{C}$.

\section{Expression analysis}

The relative expression of ten candidate $\mathrm{CHS}$ genes selected from the phylogenetic analysis was evaluated via qRT-PCR with SYBR Green QPCR Master Mix (Agilent, USA). The qPCR analysis was performed with a CFX96TM Real-Time System (Bio-Rad, USA) in a total volume of $20 \mu \mathrm{L}$ containing $10 \mu \mathrm{L}$ of $2 \times$ SYBR Green QPCR Master Mix (Agilent, USA), $0.1 \mu \mathrm{M}$ specific primers (each), and 10 ng of cDNA template. The RNA used in this experiment were extracted through Agilent Plant RNA Isolation Kit (Agilent, USA). The reaction mixtures were heated to $95{ }^{\circ} \mathrm{C}$ for $3 \mathrm{~min}$, followed by 40 cycles at $95{ }^{\circ} \mathrm{C}$ for $15 \mathrm{~s}, 60{ }^{\circ} \mathrm{C}$ for $15 \mathrm{~s}$, and $72{ }^{\circ} \mathrm{C}$ for $20 \mathrm{~s}$. The differences in gene expression were calculated using the $2^{\wedge(-\triangle \Delta \mathrm{Ct})}$ analysis method. The level of transcription was determined by relative quantification using the citrus GAPDH gene as the reference gene [48]. 

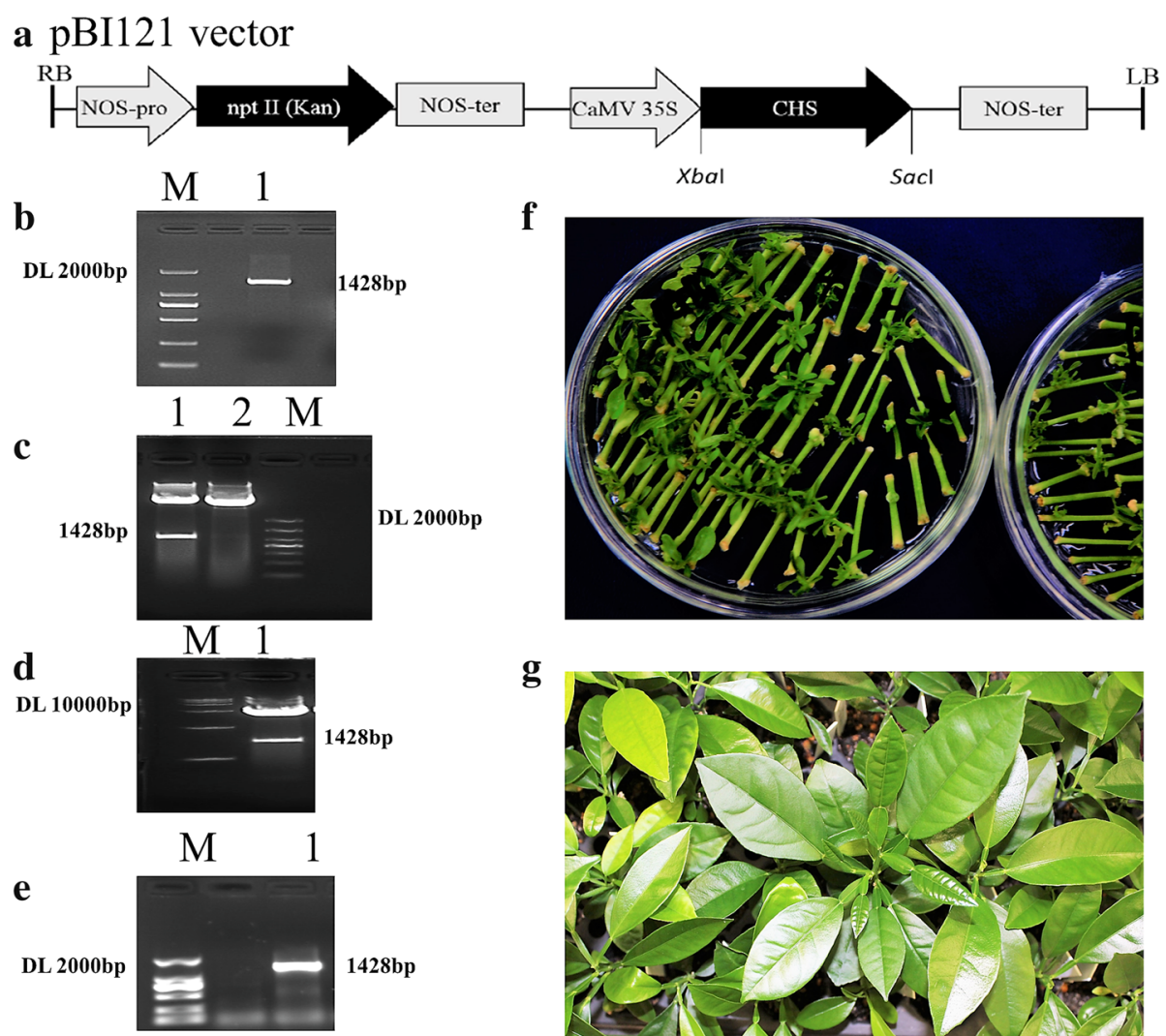

$\mathbf{g}$

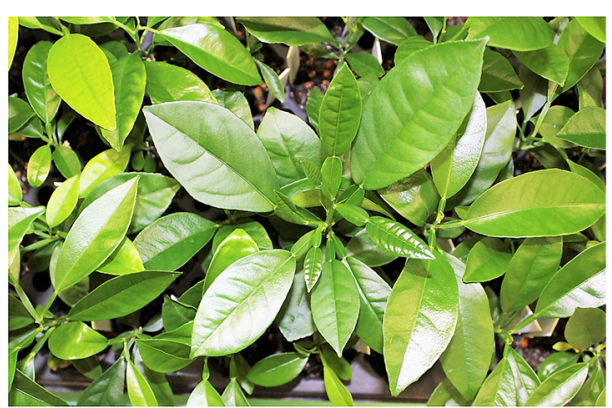

Fig. 7 Overexpression of the CitCHS2 gene in citrus plants a:1428 bp fragment containing the CitCHS2 gene ORF was constructed in the pBI121 vector. b: 1428 bp fragment was cloned via RT-PCR. M, marker; 1, 1428 bp fragment contain the ORF of CitCHS2. c: Pattern of double digestion by Xbal and Sacl of the p-EASY vector containing the 1428 bp fragment and the pBl121 vector. M, marker; 1 , the p-EASY vector containing the 1428 bp fragment; 2, the pBI121 vector. d:Validation of the constructed pBI121 and CitCHS2 ORF vector via double digestion by Xbal and Sacl. M, marker; 1, the constructed pBI121 vector. e: Colony PCR of the positive Agrobacterium tumefaciens strain EHA 105 that contains the constructed pBl121 vector. $\mathrm{M}$, marker; 1, the positive colony PCR product. $\mathbf{f}$ : Callus generated from the epicotyl of $\mathrm{C}$. sinensis after the infection of the Agrobacterium tumefaciens. $\mathbf{g}$ : Grafted positive plants grown on the rootstock

Three different RNA (of three separated biological replicates) isolations and cDNA syntheses were used as replicates for the qRT-PCR.

\section{Isolation of CHS genes}

Genomic DNA and total RNA were extracted from the young leaves of citrus plants using the CTAB method. RNA was extracted according to the protocol of the Agilent Plant RNA Isolation Kit (Agilent, USA). Gene specific primers were designed using NCBI online primer-design software (https://www.ncbi.nlm.nih.gov/tools/primer-blast/). The RT -PCR reactions were conducted through a program of $95^{\circ}$ $\mathrm{C}$ for $5 \mathrm{~min}, 58^{\circ} \mathrm{C}$ for $25 \mathrm{~s}$, and $72{ }^{\circ} \mathrm{C}$ for $1 \mathrm{~min}, 35$ cycles, at last $5 \mathrm{~min}$ time for extension. All the PCR products were purified through the QIAquick Gel Extraction Kit (QIAGEN, US) and cloned into p-EASY vectors (Transgene, China). The positive clones were sent for sequencing in Eton Bioscience Company (US). The acquired sequences were submitted to Genbank.

\section{Flavonoid detection}

The method of detecting flavones and flavonols was modified from the aluminium chloride colourimetric method reported by Woisky and Sllatino [49] and Chang [50]. The criterion solutions were generated via step by step dilution with standard quercetin and chromatography-grade methanol in consecutive concentrations of $1000 \mu \mathrm{g} / \mathrm{mL}, 500 \mu \mathrm{g} /$ $\mathrm{mL}, 250 \mu \mathrm{g} / \mathrm{mL}, 100 \mu \mathrm{g} / \mathrm{mL}, 50 \mu \mathrm{g} / \mathrm{mL}$ and $25 \mu \mathrm{g} / \mathrm{mL}$. The absorbance was measured at $415 \mathrm{~nm}$ with a Benchmark Plus microplate spectrophotometer (Bio-Rad, USA). The standard curve is in Additional file 1: Table S3-A. One gram of powdered sample was extracted twice with methanol. The first extraction was with $10 \mathrm{~mL}$ methanol, and the second was with $5 \mathrm{~mL}$ methanol. Each extraction was incubated at $50{ }^{\circ} \mathrm{C}$ and subjected to shaking at $200 \mathrm{rpm}$ for $30 \mathrm{~min}$. The residual was removed by centrifugation at $10,000 \mathrm{r} / \mathrm{min}$ for $10 \mathrm{~min}$. After a final centrifugation at $10,000 \mathrm{r} / \mathrm{min}$ for $10 \mathrm{~min}$, the $0.5 \mathrm{~mL}$ of methanol extract was reacted with aluminium chloride before measuring the absorbance at $415 \mathrm{~nm}$ with the spectrophotometer. 


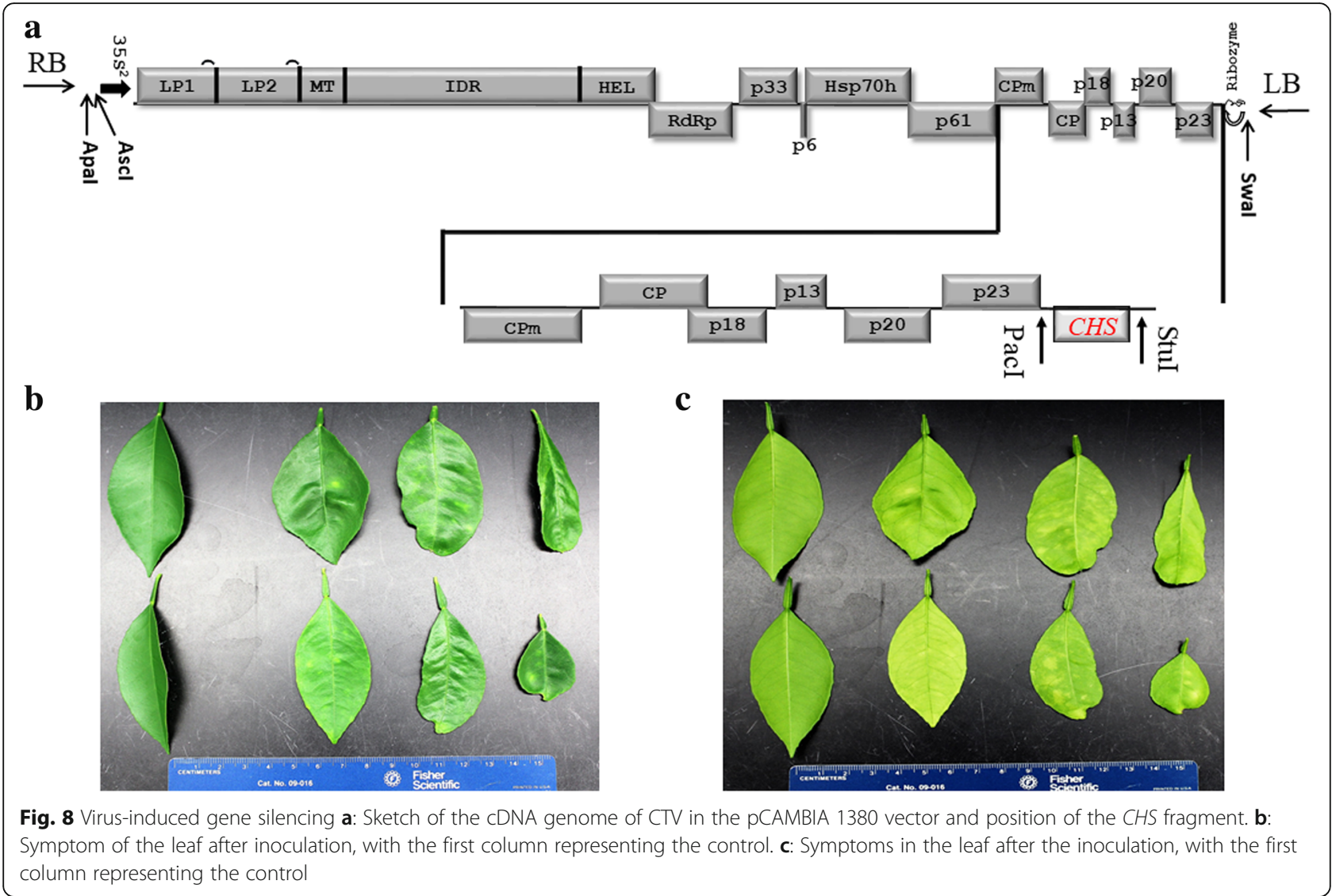

The protocol for detecting flavanones and flavanonols was slightly modified from the method described by Chang [30]. Naringenin was used as a standard chemical to generate criterion solutions at concentrations of 50 , 100, 200, 500, 1000, 3000, 4000 and $5000 \mu \mathrm{g} / \mathrm{mL}$ with methanol. The absorbance was measured at $495 \mathrm{~nm}$. The standard curve is in Additional file 1: Table S3-B. One gram of the powdered sample was extracted twice with methanol as described above and reacted with 2,4-dinitrophenylhydrazine, and the flavonoid content was determined by measuring the absorbance at $495 \mathrm{~nm}$.

\section{Overexpression of CitCHS2}

The complete ORF fragment of the CitCHS2 gene was amplified from citrus cDNA via PCR using a gene-specific primer with added $X b a \mathrm{I}$ and $S a c \mathrm{I}$ sites cloned into a p-EASY vector (Transgene, China) (Fig. $7 \mathrm{a}$ and $\mathrm{b}$ ). After confirmation by sequencing, the constructed vector was digested with the XbaI and SacI enzymes. Moreover, the PBI121 (Clontech Laboratories, USA) vector was also digested with $\mathrm{XbaI}$ and $\mathrm{SacI}$ (Fig. 7c). The digested fragments were separated on a $2 \%$ agarose gel. The ORF fragment of the CitCHS2 gene was fused to the PBI121 vector with T4 DNA ligase (Transgene, China). The plasmid was transformed into a disarmed strain of Agrobacterium tumefaciens, EH105. An empty vector of PBI121 was also transformed into EH105 as a control. The 4-week-old epicotyl of sweet orange (C. sinensis) with the same phenological period was transformed by Agrobacterium infection according to the method described by Horsch et al. [51].

\section{Virus-induced $\mathrm{CHS}$ gene silencing}

Gene-specific primers were designed from a highly conserved region of the CitCHS2 gene. A 345-nucleotide sequence was amplified for gene silencing. The fragment was fused to a CTV vector (Fig. 8a). The Agrobacterium tumefaciens strain EHA 105 was transformed with the binary plasmid containing CTV, the target gene fragment and silencing suppressors. Nicotiana benthamiana plants were used for infection to maximize the virus titre. Then, one-year-old 'Pineapple' orange trees with the same phenological period were used for inoculation infection with virions partially purified from the sap derived from agroinfiltrated $N$. benthamiana leaves [52]. The distribution of the CTV vector in the leaves of both the lower and upper parts of the plant was confirmed by ELISA according to the protocol of Garnsey [53]. A double antibody sandwich indirect enzyme-linked-immunosorbent assay (DAS-I-ELISA) [53] was used 
with purified IgG from rabbit polyclonal antibody CTV-908 $(1 \mu \mathrm{g} / \mathrm{ml})$ for coating, and a broadly reactive CTV Mab172 was used for detection. Total RNA was extracted from the leaves in the upper part of the inoculated citrus plants, and the synthesis of first-strand cDNA was performed as previously described. The integrity of the cDNA and silencing sequence were confirmed via PCR.

\section{Correlation analysis}

The correlation analysis was conducted through Pearson's correlation analysis. Three separated biological replicates in all time points (including T0) were used for analysis.

\section{Additional files}

Additional file 1: Table S1. Identify homology of CHS or CHS-like genes considered in Fig. 1. Table S2. Information of the CHS candidate genes and primers used for expression analysis. Table S3. Standard curve used in flavonoids detection. (DOCX $127 \mathrm{~kb}$ )

\section{Abbreviations}

CDS: Coding Sequence; CHI: Chalcone isomerase; CHS: Chalcone synthase; CoA: Coenzyme A; MeJA: Methyl jasmonate; PAL: Phenylalanine ammonialyase; PKS: Polyketide synthase; VIGS: Virus induced gene silencing

\section{Acknowledgements}

We are grateful to Cecile Robertson for help performing the ELISA. We also thank the China Scholarship Council (CSC) for providing financial support for the visit study of Zhibin Wang at the University of Florida.

\section{Funding}

This study was supported by Citrus Research and Development Foundation (CRDF) (00098334) and the New Varieties, Development and Management Corporation (NVDMC) (AWD02897), on behalf of the Florida citrus growers in collection, analysis, and interpretation of data and in writing the manuscript; this research was also supported by the 111 project (B18044) and the China Scholarship Council (CSC), the funders have no role in the study design, data analysis and interpretation, and manuscript writing.

\section{Availability of data and materials}

The accession numbers of the three CitCHS genes can be found in the NCBI. All data analyzed in this study are included in this published article and its supplementary information files.

\section{Authors' contributions}

Z-BW, FG and X-CZ designed the experiments; Z-BW, Q-BY, W-XS and C-AM conducted the experiment; Z-BW and C-AM carried out the virus induced gene silencing experiment; Z- Z-BW and W-XS conducted over-expression experiment; Z-BW and Q-BY measured flavonoid contents; Z-BW, Q-BY and W-XS carried out QPCR experiment; Z-BW, Q-BY and X-CZ analysed the data; Z-BW, Q-BY and W-XS prepared manuscript; FG and X-CZ supervised the research and revised the manuscript. All authors have read and approved the manuscript for publication.

\section{Ethics approval and consent to participate}

Not applicable.

\section{Consent for publication}

Not applicable.

\section{Competing interests}

The authors declare that they have no competing interests.

\section{Publisher's Note}

Springer Nature remains neutral with regard to jurisdictional claims in published maps and institutional affiliations.

Received: 18 June 2018 Accepted: 5 September 2018

Published online: 12 September 2018

\section{References}

1. Liu Y, Lou Q, Xu W, Xin Y, Bassett C, Wang Y. Characterization of a chalcone synthase (CHS) flower-specific promoter from Lilium orential 'Sorbonne. Plant Cell Rep. 2011;30(12):2187-94.

2. Tan J, Wang M, Tu L, Nie Y, Lin Y, Zhang X. The flavonoid pathway regulates the petal colors of Ccotton flower. PLoS One. 2013:8(8):e72364.

3. Yazaki K, Sugiyama A, Morita M, Shitan N. Secondary transport as an efficient membrane transport mechanism for plant secondary metabolites. Phytochem Rev. 2008;7(3):513-24

4. Goławska S, Sprawka I, Łukasik I, Goławski A. Are naringenin and quercetin useful chemicals in pest-management strategies? J Pest Sci. 2014;87(1):173-80.

5. Gabriele M, Frassinetti S, Caltavuturo L, Montero L, Dinelli G, Longo V, D Gioia D, Pucci L. Citrus bergamia powder: antioxidant, antimicrobial and anti-inflammatory properties. J Funct Foods. 2017:31:255-65.

6. Fini A, Brunetti C, Di Ferdinando M, Ferrini F, Tattini M. Stress-induced flavonoid biosynthesis and the antioxidant machinery of plants. Plant Signal Behav. 2011;6(5):709-11.

7. Peer WA, Murphy AS. Flavonoids and auxin transport: modulators or regulators? Trends Plant Sci. 2007;12(12):556-63.

8. Yao LH, Jiang YM, Shi J, FA TÁS-BÁN, Datta N, Singanusong R, Chen SS. Flavonoids in food and their health benefits. Plant Foods Hum Nutr. 2004, 59(3):113-22.

9. Tarahovsky YS, Kim YA, Yagolnik EA, Muzafarov EN. Flavonoid-membrane interactions: involvement of flavonoid-metal complexes in raft signaling. Biochim Biophys Acta Biomembr. 2014;1838(5):1235-46.

10. Chidambara Murthy KN, Kim J, Vikram A, Patil BS. Differential inhibition of human colon cancer cells by structurally similar flavonoids of citrus. Food Chem. 2012;132(1):27-34.

11. Birt DF, Hendrich $S$, Wang W. Dietary agents in cancer prevention: flavonoids and isoflavonoids. Pharmacol Ther. 2001;90(2):157-77.

12. Majo DD, Giammanco M, Guardia ML, Tripoli E, Giammanco S, Finotti E. Flavanones in Citrus fruit: structure-antioxidant activity relationships. Food Res Int. 2005;38(10):1161-6.

13. Ghasemi K, Ghasemi Y, Ebrahimzadeh MA. Antioxidant activity, phenol and flavonoid contents of 13 citrus species peels and tissues. Pak J Pharm Sci. 2009:22(3):277-81.

14. Calabrò ML, Galtieri V, Cutroneo P, Tommasini S, Ficarra P, Ficarra R. Study of the extraction procedure by experimental design and validation of a LC method for determination of flavonoids in Citrus bergamia juice. J Pharm Biomed Anal. 2004:35(2):349-63.

15. Tripoli E, Guardia ML, Giammanco S, Majo DD, Giammanco M. Citrus flavonoids: molecular structure, biological activity and nutritional properties: a review. Food Chem. 2007;104(2):466-79.

16. Guimarães R, Barros L, Barreira JCM, Sousa MJ, Carvalho AM, Ferreira ICFR. Targeting excessive free radicals with peels and juices of citrus fruits: grapefruit, lemon, lime and orange. Food Chem Toxicol. 2010;48(1):99-106.

17. Singanusong R, Nipornram S, Tochampa W, Rattanatraiwong P. Low power ultrasound-assisted extraction of phenolic compounds from mandarin (Citrus reticulata Blanco cv. Sainampueng) and lime (Citrus aurantifolia) peels and the antioxidant. Food Anal Methods. 2015;8(5):1112-23.

18. Barreca D, Bisignano C, Ginestra G, Bisignano G, Bellocco E, Leuzzi U, Gattuso G. Polymethoxylated, C- and O-glycosyl flavonoids in tangelo (Citrus reticulata $\times$ Citrus paradisi) juice and their influence on antioxidant properties. Food Chem. 2013;141(2):1481-8.

19. Tanaka Y, Brugliera F, Chandler S. Recent progress of flower colour modification by biotechnology. Int J Mol Sci. 2009;10(12):5350-69. https:// doi.org/10.3390/ijms10125350.

20. Buer CS, Imin N, Djordjevic MA. Flavonoids: new roles for old molecules. J Integr Plant Biol. 2010;52(1):98-111.

21. Kreuzaler F, Hahlbrock K. Enzymatic synthesis of aromatic compounds in higher plants: formation of naringenin (5, 7, 4'-trihydroxyflavanone) from p-coumaroyl coenzyme a and malonyl coenzyme a. FEBS Lett. 1972; 28(1):69-72. 
22. Lewinsohn E, Britsch L, Mazur Y, Gressel J. Flavanone glycoside biosynthesis in citrus chalcone synthase, UDP-glucose: flavanone-7-O-glucosyl-transferase and-rhamnosyl-transferase activities in cell-free extracts. Plant Physiol. 1989; 91(4):1323-8.

23. Winkel-Shirley B. Flavonoid biosynthesis. A colorful model for genetics, biochemistry, cell biology, and biotechnology. Plant Physiol. 2001;126(2):485-93.

24. Chaudhary PR, Bang H, Jayaprakasha GK, Patil BS. Variation in key flavonoid biosynthetic enzymes and phytochemicals in 'Rio Red' grapefruit (Citrus paradisi Macf.) during fruit development. J Agric Food Chem. 2016;64(47):9022-32

25. Martin CR. Structure, function, and regulation of the chalcone synthase. Int Rev Cytol. 1993;147:233-84

26. Sanjari S, Shobbar ZS, Ebrahimi M, Hasanloo T, Sadat-Noori S-A, Tirnaz S. Chalcone synthase genes from milk thistle (Silybum marianum): isolation and expression analysis. J Genet. 2015;94(4):611-7.

27. Zhou B, Wang Y, Zhan Y, Li Y, Kawabata S. Chalcone synthase family genes have redundant roles in anthocyanin biosynthesis and in response to blue/ UV-A light in turnip (Brassica rapa; Brassicaceae). Am J Bot. 2013;100(12): 2458-67.

28. Yahyaa M, Ali S, Davidovich-Rikanati R, Ibdah M, Shachtier A, Eyal Y,

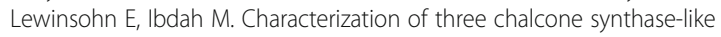
genes from apple (Malus $\times$ domestica Borkh.). Phytochemistry. 2017;140: 125-33.

29. Wang C, Zhi S, Liu C, Xu F, Zhao A, Wang X, Tang X, Li Z, Huang P, Yu M. Isolation and characterization of a novel chalcone synthase gene family from mulberry. Plant Physiol Biochem. 2017;115:107-18.

30. Tsai CJ, Ei Kayal W, Harding SA. Populus, the new model system for investigating phenyl-propanoid complexity. Int J Appl Sci Eng. 2006;4(3): 221-33

31. Tuteja JH, Clough SJ, Chan W-C, Vodkin LO. Tissue-specific gene silencing mediated by a naturally occurring chalcone synthase gene cluster in Glycine max. Plant Cell. 2004;16(4):819-35.

32. Yi JX, Derynck MR, Chen L, Dhaubhadel S. Differential expression of CHS7 and CHS8 genes in soybean. Planta. 2010;231(3):741-53.33.

33. Farzad M, Soria-Hernanz DF, Altura M, Hamilton MB, Weiss MR, Elmendorf HG. Molecular evolution of the chalcone synthase gene family and identification of the expressed copy in flower petal tissue of Viola cornuta. Plant Sci. 2005;168(4):1127-34.

34. Koes RE, Spelt CE, van den Elzen PJM, Mol JNM. Cloning and molecular characterization of the chalcone synthase multigene family of Petunia hybrida. Gene. 1989;81(2):245-57.

35. Moriguchi T, Kita M, Tomono Y, Endo-Inagaki T, Omura M. One type of chalcone synthase gene expressed during embryogenesis Rregulates the flavonoid accumulation in citrus cell cultures. Plant Cell Physiol. 1999:40(6):651-5.

36. Wang Z, Shen W, Zhu S, Xue Y, Zhao X. Polymorphism and expression of chalcone synthase gene in citrus related to the flavonoids content. Acta Horticulturae Sinica. 2015:42(3):435-44. (in Chinese)

37. Austin MB, Noel JP. The chalcone synthase superfamily of type III polyketide synthases. Nat Prod Rep. 2003:20(1):79-110.

38. Creelman RA, Tierney ML, Mullet JE. Jasmonic acid/methyl jasmonate accumulate in wounded soybean hypocotyls and modulate wound gene expression. Proc Natl Acad Sci. 1992;89(11):4938-41.

39. Deng WH, Shen YS, Chen HJ, Li ZY, Jiang XN. Effects of Dendrolimus punctatus feeding and methyl jasmonate (MeJA)-or terpenes fumigation on abscisic acid and jasmonic acid contents in Pinus massoniana seedling needles. Chin J Appl Ecol. 2009;20(5):1166-70.

40. Tuteja N, Sopory SK. Chemical signaling under abiotic stress environment in plants. Plant Signal Behav. 2008;3(8):525-36.

41. Tamari G, Borochov A, Atzorn R, Weiss D. Methyl jasmonate induces pigmentation and flavonoid gene expression in petunia corollas: a possible role in wound response. Physiol Plant. 1995;94(1):45-50.

42. Sánchez-Sampedro MA, Fernández-Tárrago J, Corchete P. Yeast extract and methyl jasmonate-induced silymarin production in cell cultures of Silybum marianum (L.) Gaertn. J Biotechnol. 2005:119(1):60-9.

43. Awasthi P, Mahajan V, Jamwal VL, Kapoor N, Rasool S, Bedi YS, Gandhi SG. Cloning and expression analysis of chalcone synthase gene from Coleus forskohlii. J Genet. 2016;95(3):647-57.
44. Lu X, Zhou W, Gao F. Cloning, characterization and localization of CHS gene from blood orange, Citrus sinensis (L.) Osbeck cv. Ruby. Mol Biol Rep. 2009; 36(7):1983-90

45. Chaudhary PR, Bang H, Jayaprakasha GK, Patil BS. Effect of ethylene degreening on flavonoid pathway gene expression and phytochemicals in Rio red grapefruit (Citrus paradisi Macf). Phytochem Lett. 2017;22:270-9.

46. Yang YN, Yao GF, Zheng D, Zhang SL, Wang C, Zhang MY, Wu J. Expression differences of anthocyanin biosynthesis genes reveal regulation patterns for red pear coloration. Plant Cell Rep. 2015;34(2):189-98.

47. Shi J, Wang L, Ma CY, Lv HP, Chen ZM, Lin Z. Aroma changes of black tea prepared from methyl jasmonate treated tea plants. J Zhejiang Univ Sci B. 2014;15(4):313-21.

48. Mafra V, Kubo KS, Alves-Ferreira M, Ribeiro-Alves M, Stuart RM, Boava LP, Rodrigues CM, Machado MA. Reference genes for accurate transcript normalization in citrus genotypes under different experimental conditions. PLoS One. 2012;7(2):e31263.

49. Woisky RG, Salatino A. Analysis of propolis: some parameters and procedures for chemical quality control. J Apic Res. 1998;37(2):99-105.

50. Chang CC, Yang MH, Wen H-M, Chern JC. Estimation of total flavonoid content in propolis by tTwo complementary colorimetric methods. J Food Drug Anal. 2002;10(3):178-82.

51. Horsch RB, Fry JE, Hoffman NL, Eichholtz D, Rogers SC, Fraley RT. A simple and general method for transferring genes into plants. Science. 1985;227: 1229-32.

52. Gowda S, Satyanarayana T, Robertson C, Garnsey S, Dawson W. Infection of citrus plants with virions generated in Nicotiana benthamiana plants agroinfiltrated with a binary vector based Citrus tristeza virus. In: International Organization of Citrus Virologists Conference Proceedings (1957-2010); 2005. p. 23-33.

53. Garnsey S: Enzyme-linked immunosorbent assay (ELISA) for citrus pathogens. Graft-transmissible diseases of citrus. Handbook for detection and diagnosis1991:193-216.

Ready to submit your research? Choose BMC and benefit from:

- fast, convenient online submission

- thorough peer review by experienced researchers in your field

- rapid publication on acceptance

- support for research data, including large and complex data types

- gold Open Access which fosters wider collaboration and increased citations

- maximum visibility for your research: over $100 \mathrm{M}$ website views per year

At $\mathrm{BMC}$, research is always in progress.

Learn more biomedcentral.com/submissions 